\title{
Investigation on sample throughput of large scale splitter-less gravitational SPLITT fractionation (GSF)
}

\author{
Hyo Jae Choi, Woon Jung Kim, Chul Hun Eum ${ }^{1}$ and Seungho Lee ${ }^{\star}$ \\ Department of Chemistry, Hannam University, Daejeon 305-811, Korea \\ ${ }^{1}$ Korea Institute of Geoscience and mineral Resources, Daejeo 305-350, Korea \\ (Received November 30, 2012; Revised December 14, 2012; Accepted December 14, 2012)
}

\section{Large scale Gravitational SPLITT Fractionation (GSF)에서의 시료 throughput에 관한 연구}

\author{
최효재 · 김운중 · 음철헌 ${ }^{1} \cdot$ 이승호 \\ 한남대학교 화학과, ${ }^{1}$ 한국지질자원연구원 지질자원특성분석센터 \\ (2012. 11. 30. 접수, 2012. 12. 14. 수정, 2012. 12. 14. 승인)
}

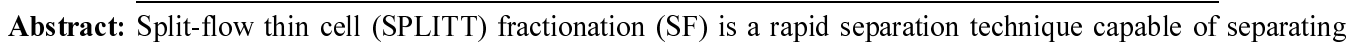
colloidal particles or macromolecules into two or more fractions. SF allows fractionations in a preparative scale as sample is fed continuously. Generally SF uses a thin ribbon-like channel equipped with two flow stream splitters at the inlet and outlet of the channel. Thus there exist two flow inlets and two flow outlets at the top and bottom of the inlet and outlet of the channel, respectively. There are two operating modes in SF, conventional mode and full-feed mode (FFD). Although the resolution in the FFD mode is lower than that in the conventional mode, FFD mode has some merits. The design of the channel and operation are simpler in the FFD mode, as it does not require the feeding of the solvent. Thus there is no flow stream splitter at the channel inlet, and only one pump is needed, unlike the conventional mode, where two pumps are required for the feedings of the sample and the solvent separately. Also the sample is not diluted in the FFD mode as there is no solvent feeding, which is important for fractionation samples with low colloidal concentrations such as environmental samples. For some of environmental samples, pre-concentration is often required. In this study, a new large-scale splitter-less FFD-SF channel was implemented, where there is no splitter at the outlet as well as at the inlet of the channel. It was possible to build the channel in a much larger dimension than conventional ones, allowing much higher sample throughput (TP). The new channel was tested and optimized with polyurethane (PU) latex beads, and then applied to large-scale separation of Polyacrylate (PA).

요 약: SPLITT Fractionation (SF)는 콜로이드 입자 및 거대분자들을 둘 혹은 그 이상의 부분(fraction)으 로 분획하는 기술이다. $\mathrm{SF}$ 에서는 시료를 지속적으로 주입하므로 대용량 분획이 가능하다. 일반적으로, $\mathrm{SF}$ 에서는 얇은 리본모양의 채널을 이용하는데, 채널의 입구와 출구부분에는 각각 flow stream splitter가 설
\end{abstract}

$\star$ Corresponding author

Phone : +82-(0)42-629-8822 Fax : +82-(0)42-629-8811

E-mail : slee@hannam.kr 
치되어 있어서 채널의 입구와 출구가 위 아래로 두 개씩 존재한다. SF에는 두 가지 작동방법이 있는데, 하나는 conventional mode 이고 다른 하나는 전액 공급 모드(full feed mode, FFD)이다. FFD 모드에서의 분리도는 conventional mode 에 비해 떨어지지만, FFD 모드에는 몇 가지 독특한 장점이 있다. FFD 모드 에서는 용매의 주입이 필요하지 않으므로 채널의 디자인 이나 작동이 더 간단하다. 따라서 입구 쪽에 flow stream splitter를 필요로 하지 않으며, 시료와 용매를 주입하기 위하여 두 개의 펌프가 필요한 conventional 모드와는 달리 한 개의 펌프만으로 작동이 가능하다. 또한 용매의 주입이 없으므로 시료가 희석되지 않는다. 이는 환경시료와 같이 콜로이드의 농도가 낮은 시료를 분획하고자 하는 경우 유리하다. 농도가 낮은 환경시료의 분획을 위해서는 종종 농축이 필요하다. 본 연구에서는 입구에는 물론 출구에도 splitter를 사용하지 않는 새로운 대용량 FFD 모드 SF 장치를 만들었다. Splitter가 없으므로 장치를 대형 화 할 수 있어서 시료처리량(throughput, $T P$ )을 크게 증가시킬 수 있었다. 산업용 폴리우레탄(polyurethane, $\mathrm{PU}$ ) 라텍스 입자들을 이용하여 새로운 SF 장치를 테스트하였으며, 폴리아크릴레이트(polyacrylate, PA) 입 자를 대상으로 새로운 $\mathrm{SF}$ 장치의 $\mathrm{TP}$ 를 확인하기 위하여 유속 및 $d_{\mathrm{c}}$ 에 따르는 $T P$ 의 변화를 조사하였다.

Key words: SPLITT, FFD throughput, polyurethane

\section{1. 서 론}

SPLITT분리법(split-flow thin cell Fractionation, $\mathrm{SF}$ ) 콜로이드 입자나 거대분자들을 두 개 혹은 그 이상의 부분(fraction)으로 분획하는 데에 유용한 빠르 고 연속적인 대용량분획 기술이다. ${ }^{1-7} \mathrm{SF}$ 는 단백질, ${ }^{5,8,9}$ 마이크론 크기의 입자, ${ }^{6,10}$ 녹말 과립제, ${ }^{10}$ 약물 운반 용 리보솜, ${ }^{11}$ 세포, ${ }^{12-14}$ 실리카 및 다이아몬드 입자, ${ }^{15}$ 전도성 입자, ${ }^{16}$ 그리고 다양한 환경물질 ${ }^{17-23}$ 과 같은 다

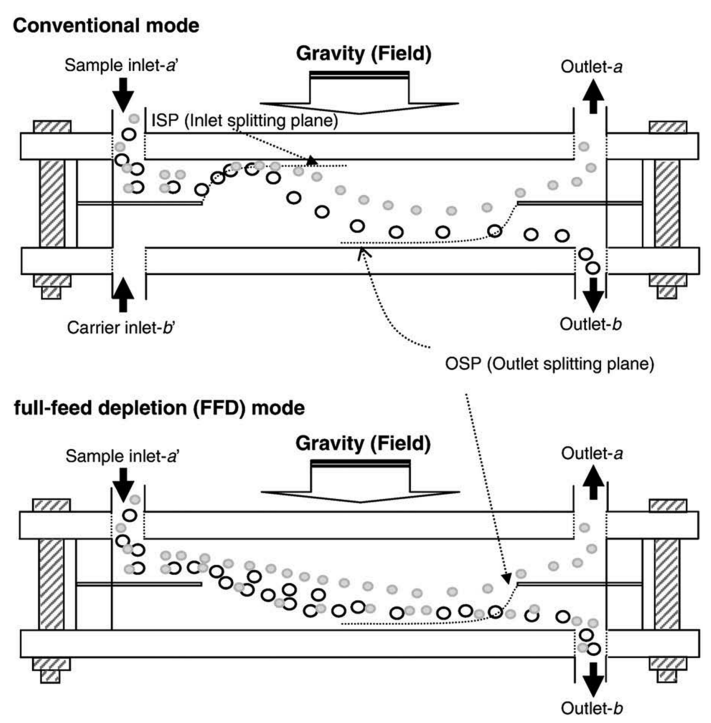

Fig. 1. Schematic views of SF channels operating in conventional (top) and full-feed depletion (FFD) mode (bottom).
양한 입자성 물질들의 분획에 성공적으로 응용되었다. $\mathrm{SF}$ 채널의 원리를 Fig. 1에 보여준다. $\mathrm{SF}$ 의 작동방법 에는 두 가지가 있는데 하나는 conventional 모드 (Fig. 1 위 그림)이고, 다른 하나는 full feed depletion (FFD) 모드(Fig. 1 아래 그림)이다.

Conventional 모드에서 사용되는 SF channel의 입구 와 출구에는 각각 flow stream-splitter가 장착되어 있 어서 두 개의 입구와 두 개의 출구를 가진다. 시료 분 산액은 $V\left(a^{\prime}\right)$ 의 유속으로 입구 $-a^{\prime}$ 를 통하여 지속적으로 공급되고, 운반용매 역시 $V\left(\mathrm{~b}^{\prime}\right)$ 의 속도로 출구 $-b$ 를 통 하여 지속적으로 공급된다. 위쪽 입구를 통하여 주입 된 시료 입자들은 운반용매의 흐름에 의해 출구 쪽으 로 이동하는데, 이 때 용매의 흐름방향에 수직으로 가 해지는 외부장(본 연구에서는 중력장)에 의해 침강한 다. 침강상수(sedimentation coefficient)가 높은 입자들 은 낮은 입자보다 더 빨리 침강한다. 시료입자가 출구 splitter에 도착하면, 출구 splitter에 의해서 출구- $a$ 혹은 출구- $b$ 로 채널을 빠져나가는데, outlet-splitting plane (OSP)보다 낮은 위치까지 가라앉는 입자는 출구- $b$ 로 빠져 나오고, 나머지는 출구- $a$ 로 빠져 나오게 되어 2 개의 부분(fraction)으로 분획된다. Conventional 모드 에서는 주입되는 시료를 채널의 위벽까지 밀어 올리 기 위해 운반 용매의 주입유속이 시료의 주입 유속보 다 더 높다(대략 10 배 정도 $)\left(V\left(\mathrm{~b}^{\prime}\right) \gg V\left(\mathrm{a}^{\prime}\right)\right)$. 운반용매의 주입으로 인하여 시료분산액은 약 10 배 정도 희석된 다. Fig. 1의 아래 그림은 Full feed depletion (FFD) 모 드의 원리를 보여준다. FFD 모드에서는 운반용매의 주입이 없으므로 시료주입을 위한 하나의 입구만 사

Vol. 26, No. 1, 2013 
용한다. 운반용매의 주입이 없어서 시료를 채널의 위 벽까지 밀어 올리지 못하므로 conventional 모드에 비 해 분리도는 낮을 수 밖에 없다. 그러나 FFD 모드는 conventional 모드에 비해 몇 가지 장점을 가지는데, 그 중 하나가 운반용매가 공급 되지 않기 때문에 시료 가 희석되지 않는다는 점이다. 이러한 장점은 비교적 시료의 농도가 낮은 환경 입자의 분획에 특히 유용하 다. 또한 하나의 입구만을 사용하므로 입구 쪽에 splitter를 필요로 하지 않는다. Splitter의 사용은 종종 splitter의 기계적인 불완전함에 의해 splitter 끝부분에서 flow stream의 난류를 발생시키므로 분리도(resolution) 의 저하를 초래한다. 또한 splitter의 존재는 $\mathrm{SF}$ 채널의 크기와 시료 처리량의 한계에 영향을 미친다.

본 연구에서는 새로운 $\mathrm{FFD}$ 모드 전용 대용량 $\mathrm{SF}$ 장 치를 개발하였다. 이 장치의 특징은 채널의 입구는 물 론 출구부분에도 splitter를 사용하지 않는다는 점이다. Splitter가 없으므로 장치의 대형화가 가능하였으며 이 는 결국 단위 시간 당 시료처리량(sample throughput, $T P$ )을 대폭 증가시킬 수 있었다. Polyurethane (PU) 및 Polyacrylate (PA) 입자들을 이용하여 새로운 장치를 테스트하고, 실험 조건 변화에 따르는 $T P$ 의 변화를 조사하였다.

\section{2. 이 론}

$\mathrm{SF}$ 에서 cut-off diameter, $d_{\mathrm{c}}$ 는 입자의 절반은 출구- $a$ 로, 나머지 절반은 출구- $b$ 로 빠져 나오는 입자직경으 로 정의된다. 따라서 이상적인 $\mathrm{SF}$ 에서 얻어지는 fraction- $a$ 에는 $d_{\mathrm{c}}$ 보다 작은 직경을 가지는 입자들만, fraction- $b$ 에는 $d_{\mathrm{c}}$ 보다 큰 직경을 가지는 입자들만 존 재한다.

$\mathrm{FFD}$ 모드에서 $d_{\mathrm{c}}$ 는 다음과 같이 주어진다. ${ }^{24}$

$$
d_{c}=\sqrt{\frac{18 \eta}{b L G \Delta \rho} V\left(a^{\prime}\right)-V(b)}
$$

식 (1)에서 $\Delta \rho$ 는 입자와 운반용매의 밀도 차이, $\eta$ 는 운반용매의 점도, $b$ 와 $L$ 은 채널의 폭과 길이, $G$ 는 중력, $V\left(\mathrm{a}^{\prime}\right)$ 와 $V(\mathrm{~b})$ 는 입구 $-a^{\prime}$ 출구 $-b$ 의에서의 유속이다.

앞에서 설명하였듯이 $\mathrm{FFD}$ 모드에서는 시료를 채널 의 위벽으로 밀어 올리지 않으므로 일부 $d_{\mathrm{c}}$ 보다 작은 입자들이 출구-b로 빠져 나오므로 conventional 모드 에 비해 분리도(resolution)는 떨어질 수 밖에 없다. 즉 fraction- $b$ 에 $d_{\mathrm{c}}$ 보다 작은 직경을 가지는 입자들이 섞 이게 된다.
FFD-SF 에서는 보통 $d_{\mathrm{c}}$ 를 먼저 선택하고, 그 다음 에 $V\left(\mathrm{a}^{\prime}\right)$ 를 선택한다. 그리고 식 (1)을 이용하여 $V(b)$ 를 구한다. $V(b)$ 가 결정되면, $V(\mathrm{a})$ 는 $V\left(\mathrm{a}^{\prime}\right)-V(\mathrm{~b})$ 가 된다. $V\left(\mathrm{a}^{\prime}\right)$ 가 높을수록 시료공급 유속이 높아지므로 시료처 리량 $(T P)$ 는 증가한다.

본 논문에서는, $\mathrm{SF}$ 의 효율을 정 량적으로 표시하기 위하여 '분획 효율' (fractionation efficiency, $F E$ )를 아 래와 같이 정의한다.

$\mathrm{FE}(\%)$ for $\mathrm{SF}$ fraction-a

number of particles smaller than $d_{c}$

$$
=\frac{\text { among measurad particles }}{\text { total number of particles measured }} \times 100
$$

$\mathrm{FE}(\%)$ for $\mathrm{SF}$ fraction-a number of particles larger than $d_{c}$

$$
=\frac{\text { among measurad particles }}{\text { total number of particles measured }} \times 100
$$

Fraction- $a$ 의 $F E$ 는 fraction- $a$ 내의 모든 입자 중에서 선택한 $d_{\mathrm{c}}$ 보다 작은 입자의 퍼센트이고, fraction- $b$ 의 $F E$ 는 fraction- $b$ 내의 모든 입자 중에서 선택한 $d_{\mathrm{c}}$ 보다 큰 입자의 퍼센트이다.

\section{3. 실 험}

\subsection{Sample}

3.1.1. Polyurethane (PU) latex bead

$1.14 \mathrm{~g} \mathrm{~mL}^{-1}$ 의 밀도를 가지는 $\mathrm{PU}$ 라텍스 입자는 산 업적 응용을 위해 대량 생산된 상품으로서 제조사로 부터 무상으로 제공받았다. 제공사의 요청으로 출처를 밝히지 않기로 한다.

\subsubsection{Polyacrylate (PA) latex bead}

$\mathrm{PA}$ 입자 역시 $1.14 \mathrm{~g} \mathrm{~mL}^{-1}$ 의 밀도를 가지며, 산업 적 응용을 위하여 대량생산된 상품으로서 제조사로부 터 무상으로 제공받았다. 본 연구에서는 두 가지 종류 의 서로 다른 입자크기분포를 가지는 PA 시료를 사용 하였다(PA-1, PA-2).

\subsection{Large scale splitter-less GSF System}

Fig. 2는 본 연구에서 제작한 대용량 splitter-less GSF 시스템의 채널 조립도를 보여준다. 채널은 두 개의 Plexiglas $^{\mathrm{TM}}$ 블록 사이에 upper블럭, Mylar spacer, middle 블록, bottom 블록을 끼워 넣음으로써 제작하 였다. 채널의 전체 길이는 $50 \mathrm{~cm}$ 이고 폭은 $10 \mathrm{~cm}$ 이 다. 입구- $a^{\prime}$ 쪽에 하나의 peristaltic pump (Masterflex, 


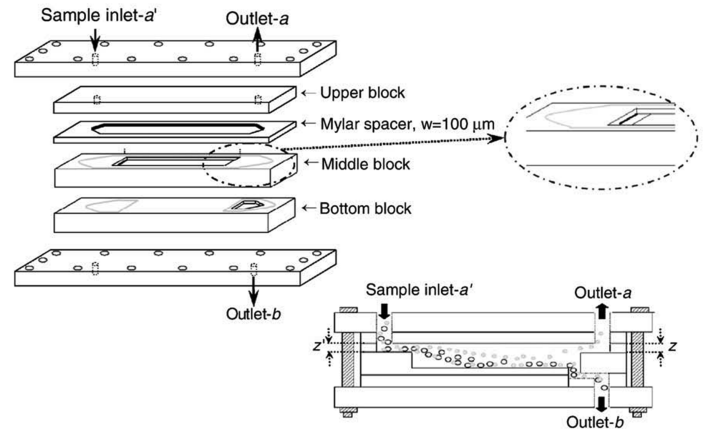

Fig. 2. Schematic view of the large scale splitter-less FFDSF channel.

Barnant, Company, Barrington IL, USA)를 연결하였 다. 모든 $\mathrm{SF}$ 실험에서 사용한 운반용매는 3 차 증류수 에 입자의 분산제 역할을 하는 FL-70 $0.1 \%$ 와 박테리 아를 제거하기 위한 sodium azide $\left(\mathrm{NaN}_{3}\right) \quad 0.02 \%$ 를 첨 가한 수용액이다.

\section{3. 광학 현미경(Optical Microscope, OM)}

광학 현미경은 Olympus BX51TF optical microscopy (Shinjuku Monolith, Shinjuku-ku, Japan)을 사용하였고 시료 입자들을 확인하고 입자크기를 측정하기 위하여 Image Inside ${ }^{\mathrm{TM}}$ software (Focus, Daejeon, Korea)의 소 프트웨어를 사용하였다.

\section{4. 결과 및 고찰}

\subsection{Large scale FFD-SF system test with PU} beads

Fig. 2의 방법으로 대용량 FFD-SF 장치를 제작하고 조립한 후, 산업용 PU 라텍스 입자 시료를 이용하여 이 장치를 테스트하였다. 이를 위하여 우선 $d_{c}$ 를 10 $\mu \mathrm{m}$ 으로 고정시키고, $V\left(\mathrm{a}^{\prime}\right)=50$ 과 $100 \mathrm{~mL} / \mathrm{min}$ 에서 실 험을 수행하였다. 출구- $b$ 에서의 유속 $V(\mathrm{~b})$ 는 22.87 $\mathrm{mL} / \mathrm{min}$ 에 고정시켰다. Fig. 3 는 $\mathrm{OM}$ 으로 측정한 분획 하기 전 PU 시료(Fig. 3-a)와 시료공급유속 50 (Fig. 3-b), $100 \mathrm{~mL} / \mathrm{min}$ (Fig. 3-c)에서 얻은 각 fraction의 입 자크기분포(size distribution)를 보여준다. Table 1에 Fig. 3의 $\mathrm{OM}$ 데이터로부터 얻은 $F E$ 값을 정리하였다.

Table 1을 보면, 시료 공급 유속 $V\left(\mathrm{a}^{\prime}\right)$ 이 $50 \mathrm{~mL} / \mathrm{min}$ 에서 $100 \mathrm{~mL} / \mathrm{min}$ 으로 증가하여 시료처리량 $(T P)$ 가 두 배 증가했을 때 Fraction- $a$ 의 $F E$ 는 78.7에서 83.6\%로, Fraction- $b$ 의 $F E$ 는 52.4 에서 $53.5 \%$ 로 각각 소폭 증가 하였다. 이는 매우 흥미로운 결과로서, 전통적인 소규

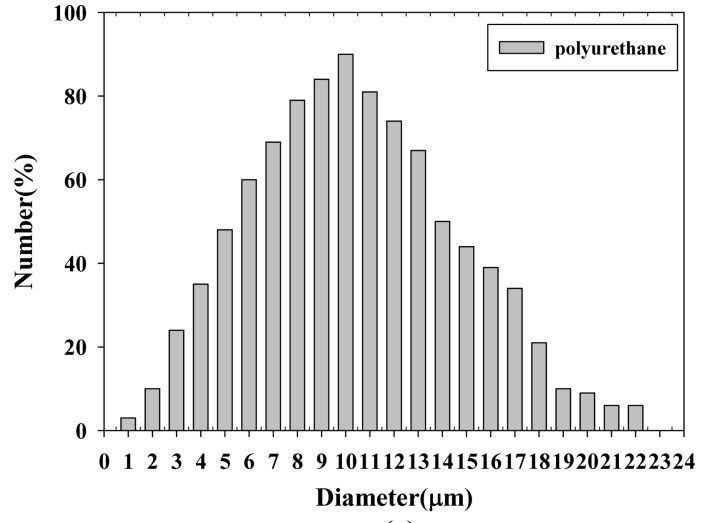

(a)
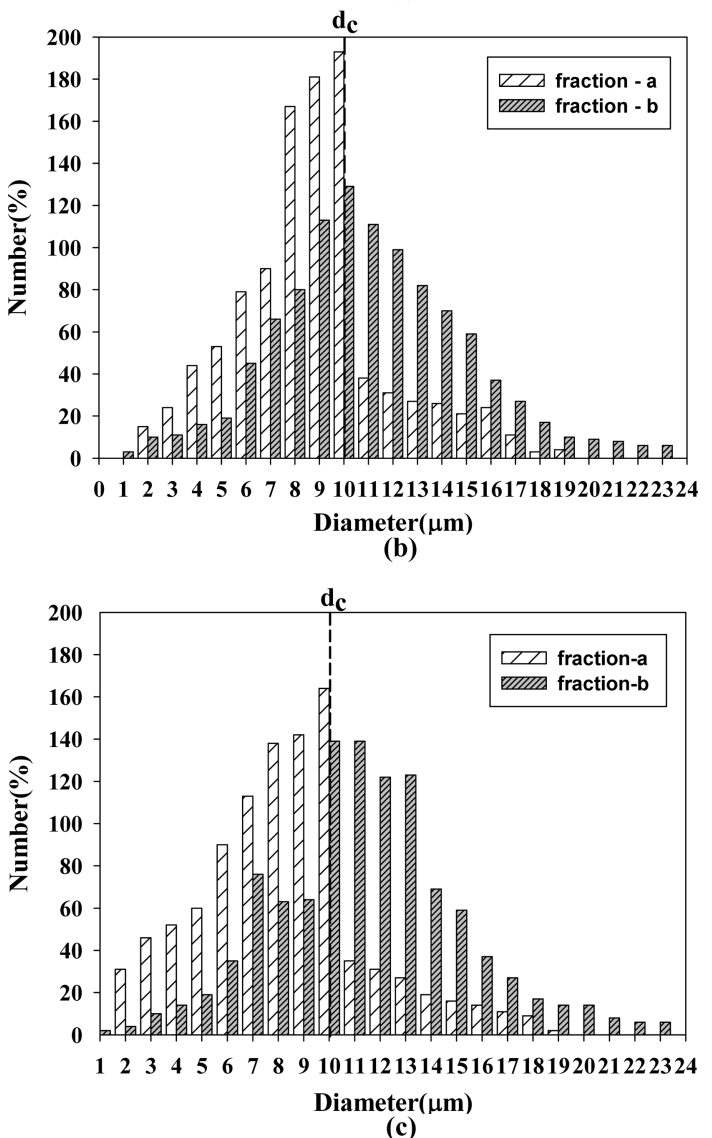

Fig. 3. OM Size distributions of PU beads (a) and their SF fractions obtained with $d_{\mathrm{c}}$ of $10 \mu \mathrm{m}$ and samplefeeding flow rate of $50 \mathrm{~mL} / \mathrm{min}(\mathrm{TP}=3 \mathrm{~kg} / \mathrm{h})(\mathrm{b})$ and $100 \mathrm{~mL} / \mathrm{min}(\mathrm{TP}=6 \mathrm{~kg} / \mathrm{hr})(\mathrm{c})$.

모의 $\mathrm{SF}$ 시스템에서 흔히 관찰되었던 시료 공급 유속 이 증가함에 따라 $F E$ 가 감소하는 경향과는 반대되는 결과이다. 이러한 결과는 본 연구에서 새로이 제작한 
Table 1. FE for SF-fractions of PU latex beads shown in Fig. 3

\begin{tabular}{|c|c|c|c|c|c|}
\hline \multirow{2}{*}{$\begin{array}{l}\text { Sample } \\
\text { loading } \\
(\mathrm{kg} / \mathrm{hr})\end{array}$} & \multirow{2}{*}{$\begin{array}{c}V\left(\mathrm{a}^{\prime}\right) \\
(\mathrm{mL} / \mathrm{min})\end{array}$} & \multicolumn{2}{|c|}{ Fraction- $a$} & \multicolumn{2}{|c|}{ Fraction- $b$} \\
\hline & & $\begin{array}{l}F E \\
(\%)\end{array}$ & $\begin{array}{c}V(\mathrm{a}) \\
(\mathrm{mL} / \mathrm{min})\end{array}$ & $\begin{array}{l}F E \\
(\%)\end{array}$ & $\begin{array}{c}V(\mathrm{~b}) \\
(\mathrm{mL} / \mathrm{min})\end{array}$ \\
\hline 3 & 50 & 78.7 & 22.87 & 52.4 & 27.13 \\
\hline 6 & 100 & 83.6 & 22.87 & 53.5 & 77.13 \\
\hline
\end{tabular}

$\mathrm{SF}$ 장치가 대용량 분획에 유리함을 보여주는 것이다. 이러한 경향에 대한 정확한 설명을 위해서는 좀 더 상세한 연구가 필요하다.

\subsection{FFD-SF fractionation of $\mathrm{PA}-1$ beads}

대용량 FFD-SF시스템을 이용하여 PA-1 입자를 연 속으로 분획하였다. $d_{c}$ 는 $4 \mu \mathrm{m}$ 로 고정하고, $V\left(\mathrm{a}^{\prime}\right)$ 를 $70,100,120 \mathrm{~mL} / \mathrm{min}$ 로 증가시켰다. Fig. 4는 $\mathrm{OM}$ 으로 측정한 분획하기 전 PA-1 시료(Fig. 4-a)와 시료공급 유속 70 (Fig. 4-b), 100 (Fig. 4-c), 120 mL/min (Fig. 4-d)에서 얻은 각 fraction의 입자크기분포를 보여준다. Table 2에 Fig. 4의 OM 데이터로부터 얻은 FE값들을 정리하였다. PU의 경우에서와 마찬가지로 시료공급

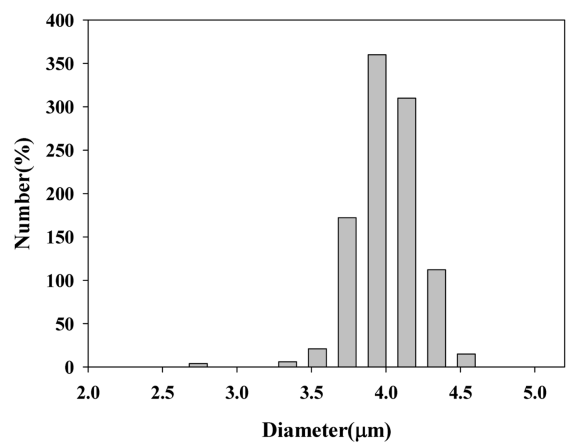

(a)

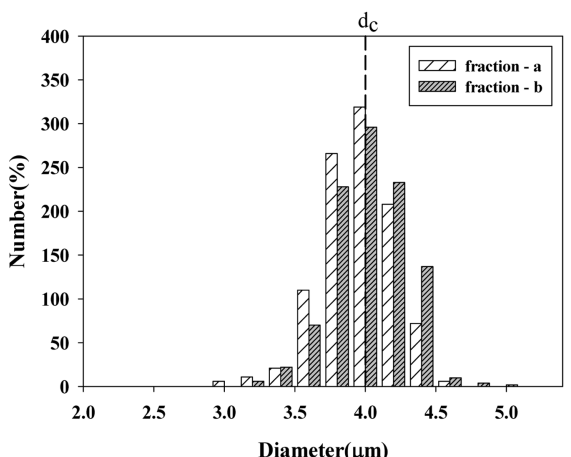

(c)
Table 2. FE measured for SF-fractions of PA-1 beads shown in Fig. 4

\begin{tabular}{cccc}
\hline \hline \multirow{2}{*}{$\begin{array}{c}\text { Sample loading } \\
(\mathrm{kg} / \mathrm{hr})\end{array}$} & $\begin{array}{c}V\left(\mathrm{a}^{\prime}\right) \\
(\mathrm{mL} / \mathrm{min})\end{array}$ & \multicolumn{2}{c}{$F E(\%)$} \\
\cline { 3 - 4 } & 70 & Fraction- $a$ & Fraction- $b$ \\
\hline 2.1 & 100 & 71.6 & 62.8 \\
3.0 & 120 & 77.0 & 67.7 \\
3.6 & & & 68.4 \\
\hline
\end{tabular}

유속이 증가함에 따라, 즉 시료처리량이 증가함에 따 라 Fraction- $a$ 의 $F E$ 는 71.6 에서 $77.0 \%$ 로 증가하였으며, Fraction- $b$ 의 $F E$ 역시 62.8 에서 $68.4 \%$ 로 점차 증가하 였다. 이는 PU의 결과와 마찬가지로, 본 연구에서 제 작한 대용량 splitter-less FFD-SF 장치가 대용량 분획 에 유용함을 보녀주는 것이다.

\subsection{FFD-SF fractionation of $\mathrm{PA}-2$ beads}

$\mathrm{PA}-2$ 시료를 분획하기 위하여 $d_{c}$ 를 $5 \mu \mathrm{m}$ 로 정하고, 시료공급유속, $V\left(\mathrm{a}^{\prime}\right)$ 를 70 과 $100 \mathrm{~mL} / \mathrm{min}$ 로하여 분획 을 수행하였다. 1 차 분획 후, fraction- $b$ 를 다시 주입하 여 2차 분획을 수행하였으며 이때 출구- $a$ 로 빠져 나

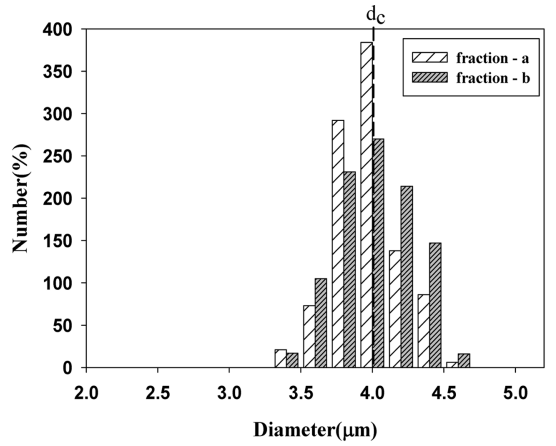

(b)

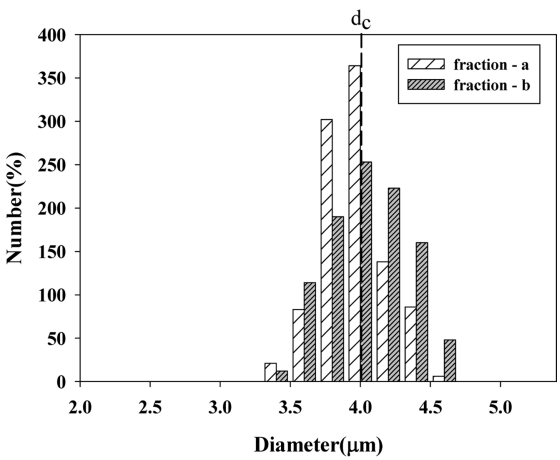

(d)

Fig. 4. OM Size distributions of PA-1 beads (A) and their SF fractions obtained with $d_{\mathrm{c}}$ of $4 \mu \mathrm{m}$ and sample-feeding flow rate of $70(B), 100(C)$, and $120 \mathrm{~mL} / \mathrm{min}(\mathrm{D})$, respectively. 


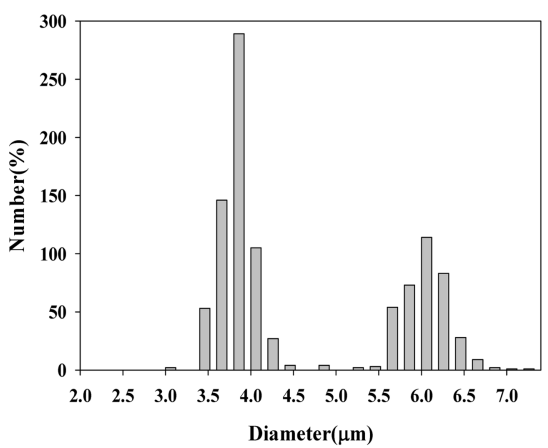

(a)

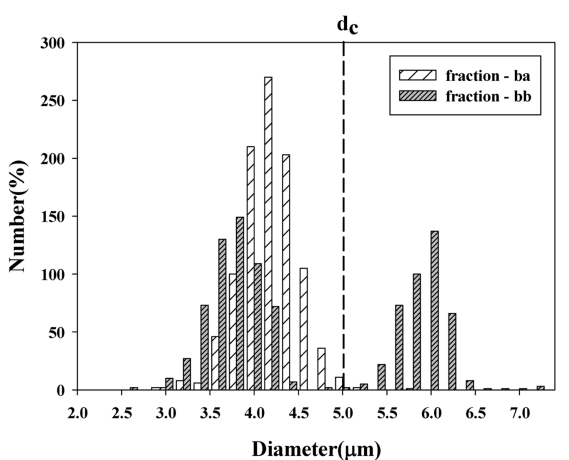

(c)

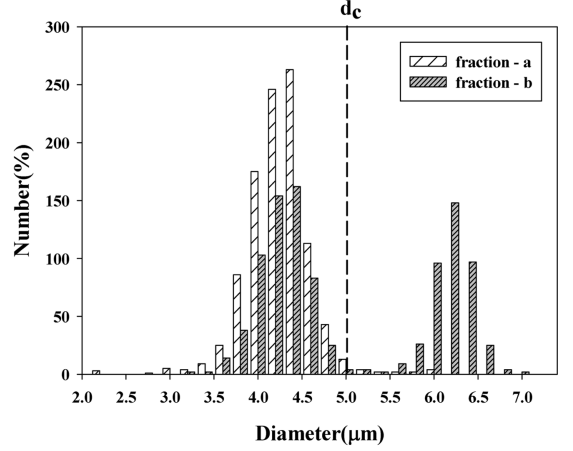

(b)

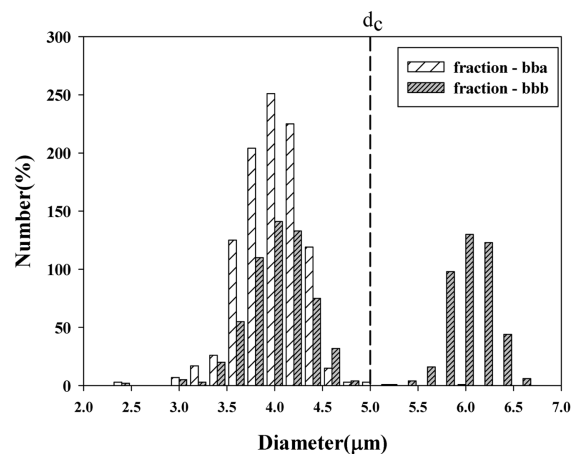

(d)

Fig. 5. OM Size distributions of PA-2 beads (A) and their SF fractions obtained by first (B), second (C) and third cycle (D) at sample-feeding flow rate of $70 \mathrm{~mL} / \mathrm{min}(\mathrm{TP}=2.1 \mathrm{~kg} / \mathrm{hr})$ with $d_{\mathrm{c}}$ set at $5 \mu \mathrm{m}$.

Table 3. FE of SF-fractions of PA-2 beads shown in Fig. 5

\begin{tabular}{ccccccc}
\hline \hline \multirow{2}{*}{$\begin{array}{c}\text { Sample loading } \\
(\mathrm{kg} / \mathrm{hr})\end{array}$} & Fraction- $a$ & Fraction- $b a$ & Fraction- $b b a$ & Fraction- $b$ & Fraction- $b b$ & Fraction- $b b b$ \\
\cline { 2 - 7 } & 98.6 & 99.5 & 99.8 & 41.7 & 41.9 & 42.2 \\
2.1 & 97.4 & 97.9 & 99.2 & 45.8 & 45.9 & 45.8 \\
\hline
\end{tabular}

온 fraction을 'fraction- $b a$ '로, 출구- $b$ 로 빠져 나온 fraction을 'fraction- $b b$ '로 각각 명명하였다. 2 차 분획 후, 또 다시 fraction- $b b$ 를 주입하여 3 차 분획을 수행 하였으며 이때 출구- $a$ 로 빠져 나온 fraction을 'fraction$b b a$ '로, 출구- $b$ 로 빠져 나온 fraction을 'fraction- $b b b$ '로 각각 명명하였다.

Fig. 5는 $\mathrm{OM}$ 으로 측정한 분획하기 전 $\mathrm{PA}-2$ 시료 (Fig. 5-a)와 1차(Fig. 5-b), 2차(Fig. 5-c), 3차(Fig. 5-d) 분획에서 얻은 각 fraction의 입자크기분포를 보여준다. $\mathrm{OM}$ 데이터로부터 얻은 각 fraction의 FE값은 Table 3 에 정리하였다.

Table 3에서 보면, $1,2,3$ 차 분획에서 출구- $a$ 로부 터 얻은 fraction- $a$, fraction- $b a$, fraction- $b b a$ 의 $F E$ 값
들은 모두 약 $97 \%$ 이상이다. 이는 시료공급유속과 무 관하게 출구- $a$ 로부터 빠져 나오는 fraction 내의 거의 모든 입자들이 $d_{c}$ 보다 작다는 것을 의미한다. 따라서 비록 $d_{c}$ 보다 작은 입자들의 일부가 출구- $b$ 로 빠져나감 으로 해서 $100 \%$ 회수는 불가능하지만, 본 대용량 FFD-SF 장치를 이용하면 일정크기 이상의 입자들만 분 획할 수 있음을 보여준다. Table 3 는 $1,2,3$ 차 분획에 서 출구- $b$ 로부터 얻은 fraction- $b$, fraction- $b b$, fraction$b b b$ 의 $F E$ 값들은 모두 약 $40 \sim 45 \%$ 범위에 있음을 보 여준다.

PA-1과 PA-2 시료의 분획 결과를 비교해 보면 흥미 로운 결과를 볼 수 있다. 출구 $a$ 로부터 얻은 PA-1 fraction들의 $F E$ 값들이 약 $70 \%$ 범위에 있는데 비해, 
Table 4. FE of mixed SF-fractions of PA-2 beads shown in Fig. 5

\begin{tabular}{cccc}
\hline \hline \multirow{2}{*}{$\begin{array}{c}\text { Sample loading } \\
(\mathrm{kg} / \mathrm{hr})\end{array}$} & Fraction- $a$ & $\begin{array}{c}\text { Fraction- } \\
(b a+a)\end{array}$ & $\begin{array}{c}\text { Fraction- } \\
(b b a+b a+a)\end{array}$ \\
\cline { 2 - 4 } & 98.6 & 99.5 & 99.8 \\
2.1 & 97.4 & 97.9 & 98.2 \\
\hline
\end{tabular}

PA-2 fraction 들의 $F E$ 값들은 이보다 훨씬 높은 약 $97 \%$ 이상이다. 반면에 출구- $b$ 부터 얻은 PA-1 fraction 들의 $F E$ 값들이 약 $60 \%$ 범위에 있는데 비해, PA-2 fraction 들의 $F E$ 값들은 이보다 훨씬 낮은 약 $40 \%$ 범 위에 있다. PA-1 시료와 PA-2 시료는 동일한 방법으 로 합성된 PA 입자들이며 입자크기분포만 다르다. PA-1 시료의 입자크기분포가 PA-2 시료의 입자크기분 포보다 좁다. 위의 결과는 시료의 입자크기분포가 넓 을수록 fraction- $a$ 의 $F E$ 는 향상되고, fraction- $b$ 의 $F E$ 값은 낮아지는 경향을 보임을 알 수 있다

Table 4는 PA-2 시료의 1차 분획에서 얻은 fraction$a$, fraction- $a$ 와 2 차 분획에서 얻은 fraction- $b a$ 의 혼합 물 (fraction- $(a+b a)$ ), 그리고 fraction- $(a+b a)$ 와 3 차 분 획에서 얻은 fraction- $b b a$ 의 혼합물(fraction- $(a+b a+b b a)$ ) 의 $F E$ 값들을 보여준다. 기대했던 대로, 두 유속조건에 서 모두 fraction- $a$, fraction- $(a+b a)$, fraction- $(a+b a+b b a)$ 의 순으로 $F E$ 값이 점차 증가함을 알 수 있다. 이는 FFD-SF에서, 분획을 반복함으로써 각 fraction의 $F E$ 값을 향상시킬 수 있음을 보여준다.

\section{5. 결 론}

본 연구는 대용량 splitter-less FFD-SF 장치를 setup 하고, 테스트한 결과를 보여준다. 실험 결과로 볼 때, splitter가 없는 FFD-SF 장치는 계속 노력하여 디자인 을 더욱 개선한다면 입자성 물질의 대용량 분획에 매 우 유용한 도구가 될 것으로 기대된다. 대용량 splitterless FFD-SF 장치는 대용량 분획을 제공함은 물론, $\mathrm{SF}$ 작동을 쉽고 단순하게 해준다. 전통적인 장치에서와는 달리 하나의 펌프만을 필요로 하며, splitter를 사용하 지 않으므로 flow stream의 난류발생을 우려할 필요가 없다. 특히 시료공급 유속을 증가시킬 때, fraction- $a$ 와 $b$ 의 $F E$ 가 함께 증가함을 관찰하였으며, 이는 이 장치 가 대용량 분획에 더 적합함을 증명하는 것이다. 이러 한 결과에 대한 정확한 설명을 위해서는 좀 더 면밀 한 연구가 요구된다. 앞으로는 fraction- $b$ 에 존재하는 $d_{\mathrm{c}}$ 보다 작은 직경을 가지는 입자들의 상대적인 양을 줄이는, 즉 fraction- $b$ 의 $F E$ 를 높이고자 하는 노력을 시도할 계획이다. 또한 본 연구에서 사용한 구형입자 외에 비구형 입자에 적용하여 그 결과를 구형입자의 경우와 비교함으로써 입자크기뿐만 아니라 입자모양 의 영항을 조사해 볼 계획이다.

\section{감사의 글}

본 연구는 교육과학기술부의 재원으로 한국연구재 단의 지원을 받아 수행되었습니다(2010-0003133).

\section{참고문헌}

1. J. C. Giddings, Sep. Sci. Technol., 20(9-10), 749-768 (1985).

2. S. R. Springston, M. N. Myers and J. Calvin Giddings, Anal. Chem., 59(2), 344-350 (1987).

3. J. C. Giddings, Sep. Sci. Technol., 23(1-3), 119-131 (1988).

4. J. C. Giddings, Sep. Sci. Technol., 23(8-9), 931-943 (1988).

5. S. Levin, M. N. Myers and J. C. Giddings, Sep. Sci. Technol., 24(14), 1245-1259 (1989).

6. Y. Gao, M. N. Myers, B. N. Barman and J. Calvin Giddings, Part. Sci. Technol., 9(3-4), 105-118 (1991).

7. J. C. Giddings, Sep. Sci. Technol., 27(11), 1489-1504 (1992).

8. P. S. Williams, S. Levin, T. Lenczycki and J. C. Giddings, Ind. Eng. Chem. Res., 31(9), 2172-2181 (1992).

9. C. B. Fuh and J. C. Giddings, Sep. Sci. Technol., 32(18), 2945-2967 (1997).

10. C. B. Fuh, M. N. Myers and J. C. Giddings, Anal. Chem., 64(24), 3125-3132 (1992).

11. S. Levin and G. Tawil, Anal. Chem., 65(17), 2254-2261 (1993).

12. S. Levin and J. C. Giddings, J. Chem. Technol. Biotechnol., 50(1), 43-56 (1991).

13. J. Zhang, P. S. William, M. N. Myers and J. C. Giddings, Sep. Sci. Technol., 29(18), 2493-2522 (1994).

14. C. B. Fuh, E. M. Trujillo and J. C. Giddings, Separation Science Technology, 3861-3876 (1995).

15. Y. Jiang, A. Kummerow and M. Hansen, J. Microcolumn Sep., 9(4), 261-273 (1997). 
16. Y. Jiang, M. E. Miller, M. E. Hansen, M. N. Myers and P. S. Williams, J. Magn. Magn. Mater., 194(1), 53-61 (1999).

17. R. G. Keil, E. Tsamakis, C. B. Fuh, J. C. Giddings and J. I. Hedges, Geochim. Cosmochim. Acta, 58(2), 879893 (1994).

18. C. Contado, F. Dondi, R. Beckett and J. C. Giddings, Anal. Chim. Acta, 345(1-3), 99-110 (1997).

19. F. Dondi, C. Contado, G. Blo and S. Garia Martin, Chromatographia, 48(9-10), 643-654 (1998).

20. M. H. Moon, S. G. Yang, J. Y. Lee and S. Lee, Anal.
Bioanal. Chem., 381(6), 1299-1304 (2005).

21. M. H. Moon, D. Kang, H. Lim, J. E. Oh and Y. S. Chang, Environ. Sci. Technol., 36(20), 4416-4423 (2002).

22. M. H. Moon, D. Kang, L. Dai Woon and Y. S. Chang, Anal. Chem., 73(3), 693-697 (2001).

23. C. Contado and F. Dondi, J. Sep. Sci., 26(5), 351-362 (2003).

24. M. N. Myers, Y. Jiang and J. C. Giddings, Proceeding of the Fifth International Symposium on Field-Flow Fractionation, Utah, USA, 37-38 (1995). 